\title{
KAJIAN HUKUM PEMBAGIAN HARTA BERSAMA DI PENGADILAN AGAMA KABUPATEN NGANJUK (Studi Perkara Nomor 338/Pdt.G/2008/PA.NGJ)
}

\author{
Syaiful Muda'i \\ Fakultas Hukum Institut Agama Islam Pangeran Diponegoro \\ J1. HOS Cokroaminoto No.52, Kauman, Kabupaten Nganjuk, Jawa Timur
}

\begin{abstract}
Research on the division of property with due to divorce this studied from the implementation of the division of property together in practice in the religious court Nganjuk the case number of 338 / pdt.g / 2008 / PA.NGJ, with an applicant Abdussalam bin Kohar VS Nur Hayati binti Abu Bakar Abdussalam as termohon which in rekonpensi filed a lawsuit rekonpensi to an applicant about the division of property with (gono-gini) obtained during marriage, a living period and this idah and mut'ah .Formulation trouble is: 1. How study law the division of property together in the religious court Nganjuk in matter number 338 / pdt.G / 2008 / PA.NGJ? 2. How the implementation of the / execution the division of property along on matter number 338 / pdt.G / 2008 / PA.NGJ? The kind of research this is research law empirical .The result of this research is: 1. The division of property together in the religious court Nganjuk in matter number number 338 / pdt.G / 2008 / PA. NGJ, done on the basis of the law number 1 of 1974 about the marriages and compilation Islamic law, So the wealth that obtained either from the husband or wife be joint right unless there is otherwise stated in agreement marriage and if marriage drop out, each entitled 1/2 ( half than all the, because during marriage there are the wealth with, so judge here ruling on the size of the parts of each. A court establish the division of property with the half to the plaintiff and half to a defendant. 2. To the execution the division of property along on matter number 338 / pdt.G / 2008 / PA.NGJ, is done on a voluntary basis by the parties because they were not so make an issue of whether judicial decisions religion Nganjuk, because the main objective of they the plaintiff and the defendant is divorced.
\end{abstract}

Keyword: Law, The Division Of, Wealth With, The Religious Court 


\begin{abstract}
ABSTRAK
Penelitian tentang pembagian harta bersama akibat perceraian ini dikaji dari Pelaksanaan Pembagian Harta Bersama dalam Praktek di Pengadilan Agama Nganjuk nomor perkara 338/Pdt.G/2008/PA.NGJ dengan pemohon Abdussalam bin Kohar melawan Nur Hayati binti Abu Bakar sebagai termohon yang dalam rekonpensi mengajukan gugatan rekonpensi kepada pemohon mengenai pembagian harta bersama / gono-gini yang diperoleh selama perkawinan, nafkah iddah dan mut'ah. Rumusan masalah adalah: 1. Bagaimana kajian hukum pembagian harta bersama di Pengadilan Agama Nganjuk pada perkara nomor Nomor 338/Pdt.G/2008/PA.NGJ? 2. Bagaimana pelaksanaan/eksekusi pembagian harta bersama pada perkara Nomor 338/Pdt.G/2008/PA.NGJ ? Jenis penelitian ini adalah penelitian hukum Empiris. Hasil penelitian ini adalah: (1) Pembagian harta bersama di Pengadilan Agama Nganjuk pada perkara nomor Nomor 338/Pdt.G/2008/PA.NGJ dilakukan atas dasar Undang-Undang Nomor 1 Tahun 1974 tentang Perkawinan dan Kompilasi Hukum Islam, maka harta kekayaan yang diperoleh baik dari pihak suami atau isteri menjadi hak bersama sepanjang tidak ditentukan lain dalam perjanjian perkawinan dan jika perkawinan putus, masing-masing berhak $1 / 2$ (seperdua) dari harta tersebut, karena selama perkawinan terdapat adanya harta bersama, maka Hakim disini memberikan putusan mengenai besarnya bagian masing-masing. Pengadilan menetapkan pembagian harta bersama tersebut seperdua untuk penggugat dan seperdua untuk tergugat. 2. Pelaksanaan eksekusi pembagian harta bersama pada perkara Nomor 338/Pdt.G/2008/PA.NGJ adalah dilakukan dengan sukarela oleh para pihak karena mereka tidak begitu mempermasalahkan putusan pengadilan Agama Nganjuk, karena tujuan utama mereka (penggugat dan tergugat) adalah bercerai.
\end{abstract}

Kata kunci: Hukum, Pembagian, Harta Bersama, Pengadilan Agama 


\section{A. PENDAHULUAN}

\section{Latar Belakang Masalah}

Perkawinan merupakan hal yang sangat penting bagi setiap individu, dalam perkawinan akan terbentuk suatu keluarga yang diharapkan akan tetap bertahan hingga pasangan tersebut dipisahkan oleh keadaan dimana salah satunya meninggal dunia. Perkawinan dianggap penyatuan antara dua jiwa yang sebelumnya hidup sendiri-sendiri, begitu gerbang perkawinan sudah dimasuki, masing-masing individu tidak bisa lagi memikirkan diri sendiri akan tetapi harus memikirkan orang lain yang bergantung hidup kepadanya.

Dalam Undang-Undang Nomor 1 Tahun 1974 tentang Perkawinan Pasal 1 menyatakan bahwa perkawinan adalah ikatan lahir bathin antara seorang pria dan wanita sebagai suami istri dengan tujuan membentuk keluarga (rumah tangga) yang bahagia dan kekal berdasarkan Ketuhanan Yang Maha Esa.

Berdasarkan pengertian tersebut di atas dapat dikatakan bahwa tujuan utama dari perkawinan adalah membentuk keluarga yang bahagia dan kekal sampai ajal memisahkan pasangan suami istri itu dengan berlandaskan kepada Ketuhanan Yang Maha Esa. Berawal dari perkawinan inilah akan terbentuk sebuah keluarga yang beranggotakan ayah, ibu dan anak-anak, dimana seorang ayah bertindak sebagai pemimpin keluarga dan memenuhi segala kebutuhan yang diperlukan semua anggota keluarga. Ibu bertindak lebih banyak dalam fungsi pengawasan kepada anak-anak dan membantu suami memenuhi kebutuhan yang diperlukan untuk menjalankan organisasi kecil yang disebut keluarga ini. Antara semua anggota keluarga satu sama lainnya memiliki hubungan timbal balik yang tidak terpisahkan.

Dalam keluarga suami dan istri merupakan bagian inti, hubungan mereka mencerminkan bagaimana satu manusia dengan manusia yang lainnya berbeda jenis kelamin bersatu membentuk kesatuan untuk mempertahankan hidup dan menciptakan keturunan yang sesuai dengan 
cita-cita bangsa Indonesia, sehingga bisa dibayangkan jika tanpa suami ataupun istri keluarga tidak dapat terbentuk dan masyarakatpun tidak akan pernah ada untuk membentuk kesatuan yang lebih besar yaitu suatu Negara. Hal ini memperlihatkan kepada kita betapa pentingnya perkawinan dalam tatanan kehidupan manusia.

Semua individu yang sudah memasuki kehidupan berumah tangga pasti mengiginkan terciptanya suatu rumah tangga yang bahagia, sejahtera lahir dan batin serta memperoleh keselamatan hidup dunia maupun akhirat nantinya. Tentu saja dari keluarga yang bahagia ini akan tercipta suatu masyarakat yang harmonis dan akan tercipta masyarakat rukun, damai, adil dan makmur. Setiap pasangan suami istri pasti mendambakan keharmonisan berumah tangga, sehingga diperlukan perjuangan untuk mempertahankan keutuhan rumah tangga sampai ajal menjemput nantinya, hal ini dikarenakan dalam keluarga akan selalu muncul permasalahan yang sangat bisa mengoyahkan persatuan yang dibina tadi, bahkan keutuhan keluarga yang kuat bisa terancam dan berakibat kepada perceraian.

Prinsip perkawinan adalah untuk membentuk suatu keluarga atau rumah tangga yang tentram, damai dan kekal untuk selama-lamanya, makanya proses untuk menuju perceraian itu tidaklah gampang bahkan dipersulit, suami tidak bisa begitu saja menjatuhkan talak kepada istri demikianpun sebaliknya istri tidak bisa lansung meminta cerai kepada suaminya. Baik suami ataupun istri diberikan kesempatan untuk mencari penyelesaian dengan jalan damai yakni dengan jalan musyawarah, jika masih belum terdapat kesepakatan dan merasa tidak bisa melanjutkan keutuhan keluarga maka barulah kedua belah pihak bisa membawa permasalahan ini ke pengadilan untuk dicari jalan keluar yang terbaik.

Upaya terakhir yang ditempuh seandainya tidak mendapat jalan keluar yang sesuai melalui musyawarah adalah meminta kepada pengadilan untuk menyelesaikan permasalahan suami istri tadi. Pengadilan akan membuka kembali pintu perdamaian kepada para pihak dengan cara musyawarah memakai penengah yakni hakim, untuk orang yang beragama 
Islam akan membawa permasalahan ini kepada Pengadilan Agama sementara untuk agama lainnya merujuk kepada Pengadilan Negeri tempat mereka tinggal.

Perceraian bukan saja dikarenakan hukum agama dan perundangundangan, tetapi juga berakibat sejauh mana pengaruh budaya malu dan kontrol dari masyarakat, pada masyarakat yang kekerabatannya sangat kuat, perceraian adalah kata sulit yang dikeluarkan tetapi pada masyarakat yang memiliki kelemahan sistem kekerabatannya maka akan mudah terjadi perceraian. $^{51}$

Suatu perceraian akan membawa berbagai akibat hukum, salah satunya adalah berkaitan dengan harta bersama dalam perkawinan. Undang-undang Nomor 1 Tahun 1974 tentang Perkawinan mengatur tentang harta bersama, antara lain: Pasal 35 (1) Menyatakan harta benda yang diperoleh sepanjang perkawinan menjadi harta bersama. (2) Harta bawaan dari masing-masing suami dan istri dan harta benda yang diperoleh masing-masing sebagai hadiah atau warisan adalah di bawah penguasan masing-masing si penerima, para pihak tidak menentukan lain. Pasal 36 (1) Mengenai harta bersama suami dan istri dapat bertindak atas persetujuan kedua belah pihak. (2) Mengenai harta bawaan masingmasing, suami dan istri mempunyai hak sepenuhnya untuk melakukan perbuatan hukum mengenai harta bersama. Pasal 37 (1) Bilamana perkawinan putus karena perceraian maka harta bersama diatur menurut hukumnya masing-masing. Dalam penjelasan Pasal 37 ayat (1) ini ditegaskan hukum masing-masing ini ialah hukum agama, hukum adat dan hukum-hukum lainnya yang bersangkutan dengan pembagian harta bersama tersebut. ${ }^{52}$

Harta bersama ada pada saat perkawinan berlansung sedangkan harta bawaan diperoleh sebelum berlangsungnya perkawinan, namun kenyataannya dalam keluarga-keluarga di Indonesia banyak yang tidak

\footnotetext{
h. 145 .

${ }^{51}$ Hilman Hadikusuma, Hukum Perkawinan Adat, PT Citra Aditya Bakti, Bandung 1990,

${ }^{52}$ Lihat Undang-undang Nomor 1 Tahun 1974 tentang Perkawinan
} 
mencatat tentang harta bersama yang mereka miliki. Pada perkawinan yang masih baru pemisahan harta bawaan dan harta bersama itu masih nampak, akan tetapi pada usia perkawinan yang sudah tua, harta bawaan maupun harta bersama itu sudah sulit untuk dijelaskan secara terperinci satu persatu. ${ }^{53}$

Hal yang paling sering terjadi pada masyarakat Indonesia yang mayoritas beragama Islam saat ini adalah setelah terjadinya perceraian, mengenai kedudukan atau pembagian harta bersama antara suami dan istri yang bercerai tersebut, banyak masyarakat yang memilih Pengadilan Agama untuk menyelesaikan pertikaian pembagian harta bersama.

Pembagian harta bersama menurut ketentuan Pasal 37 UndangUndang Nomor 1 tahun 1974 tentang Perkawinan tidak ditetapkan secara tegas berapa bagian masing-masing suami atau istri yang bercerai baik cerai hidup maupun cerai mati.

Selain Undang-Undang Nomor 1 Tahun 1974 tentang Perkawinan, di Indonesia juga berlaku Kompilasi Hukum Islam, yang berkaitan dengan pembagian harta bersama sebagaimana diatur dalam Pasal 96 dan 97 Kompilasi Hukum Islam tersebut, yang menyebutkan bahwa pembagian harta bersama baik cerai hidup maupun cerai mati ini, masing-masing mendapat setengah dari harta bersama tersebut. Selengkapnya Pasal 96 Kompilasi Hukum Islam berbunyi :

a. Apabila terjadi cerai mati, maka separo harta bersama menjadi hak pasangan yang hidup lebih lama.

b. Pembagian harta bersama bagi seorang suami atau istri yang istri atau suaminya hilang harus ditanguhkan sampai adanya kepastian matinya yang hakiki atau mati secara hukum atas dasar keputusan Pengadilan Agama.

Sedangkan Pasal 97 Kompilasi Hukum Islam menyatakan: "Janda atau duda yang cerai hidup masing-masing berhak seperdua dari harta bersama sepanjang tidak ditentukan lain dalam perjanjian perkawinan". ${ }^{54}$

\footnotetext{
${ }^{53}$ Hadikusuma, Op.Cit, h.56.

${ }^{54}$ Lihat Kompilasi Hukum Islam
} 
Dari uraian diatas, dapat diambil pengertian bahwa pembagian harta bersama karena cerai hidup dapat dilakukan secara langsung antara bekas istri dan suami dengan pembagian masing-masing separo bagian.

Perkara yang menyangkut perceraian dan kemudian berlanjut dengan pembagian harta bersama ini terjadi di seluruh wilayah Indonesia termasuk di Kabupaten Nganjuk masyarakatnya beragama Islam dan tentunya penyelesaian kasus pembagian harta bersama ini berada dalam kewenangan Pengadilan Agama.

Berkaitan dengan pembagian harta bersama akibat perceraian ini penulis ingin mengkaji lebih jauh yakni dengan melakukan penelitian tentang Pelaksanaan Pembagian Harta Bersama dalam Prakteknya di Pengadilan Agama Nganjuk dalam nomor perkara 338/Pdt.G/2008/PA.NGJ dengan pemohon Abdussalam bin Kohar melawan Nur Hayati binti Abu Bakar sebagai termohon yang dalam rekonpensi mengajukan gugatan rekonpensi kepada pemohon mengenai pembagian harta bersama/gono-gini yang diperoleh selama perkawinan, nafkah iddah dan mut'ah.

\section{Rumusan Masalah}

a. Bagaimana kajian hukum pembagian harta bersama di Pengadilan Agama Nganjuk pada perkara nomor Nomor 338/Pdt.G/2008/PA.NGJ

b. Bagaimana pelaksanaan/eksekusi pembagian harta bersama pada perkara Nomor 338/Pdt.G/2008/PA.NGJ

\section{Tujuan Penelitian}

a. Untuk mengkaji secara mendalam pembagian harta bersama di Pengadilan Agama Nganjuk pada perkara nomor Nomor 338/Pdt.G/2008/PA.NGJ

b. Untuk mengkaji secara mendalam pelaksanaan/eksekusi pembagian harta bersama pada perkara Nomor 338/Pdt.G/2008/PA.NGJ 


\section{B. PEMBAHASAN}

Pembagian harta kekayaan dalam perkawinan senantiasa merupakan bagian yang krusial dari suatu perceraian. Hal ini dapat kita cermati dari banyaknya kasus yang menarik perhatian publik terhadap pembagian harta perkawinan :

Pembagian harta bersama lewat Pengadilan Agama, bisa diajukan serempak dengan pengajuan gugatan perceraian (kumulatif) atau dapat pula digugat tersendiri setelah putus perceraian baik secara langsung oleh yang bersangkutan maupun memakai jasa pengacara. Pemeriksaan pembagian harta bersama dalam hal yang kumulatif dilakukan setelah pemeriksaan gugatan cerai. Apabila gugatan cerainya ditolak, maka pembagian harta bersamanya biasanya juga di tolak. Karena pembagian harta bersama tersebut menginduk pada gugatan cerai. Kecuali kalau minta pemisahan harta bersama, karena salah satu pihak dikuatirkan atau bahkan terbukti menghilangkan harta bersama dengan permohonan tersendiri. ${ }^{55}$

Syarat-syarat mengajukan gugatan permohonan pembagian harta bersama di Pengadilan Agama Kupaten Nganjuk ialah :

1. Mengajukan perkara atau surat gugatan ke Pengadilan Agama

2. Penggugat mendaftarkan perkara yang akan diajukan

3. Foto copy KTP yang menunjukkan sebagai Warga Negara Indonesia.

4. Terdapatnya harta bersama yang telah diperoleh selama perkawinan.

5. Adanya akte perceraian (apabila sudah cerai)

6. Mengajukan biaya perkara perskot atau panjer biaya perkara sewaktu surat gugatan didaftarkan di kepaniteraan. ${ }^{56}$

Mengajukan biaya perkara setelah perkara diputus di Pengadilan. Setelah syarat-syarat untuk mengajukan gugatan terpenuhi, maka proses pernbagian harta bersama baru dapat diproses di Pengadilan Agama. Bahwa pada pokoknya penggugat (mantan isteri) mengajukan gugatan pembagian harta bersama. Dimana penggugat mengajukan permohonan tambahan berupa permohonan sita jaminan (Conservaloir beslag). Sita ini dilaksanakan ataspermohonan para pihak yang bersengketa artinya sita hanya dapat

\footnotetext{
${ }^{55}$ Hasil wawancara dengan Ketua Pengadilan Agama Kabupaten Nganjuk, tanggal 29 April 2015

${ }^{56}$ Hasil Wawancara dengan Panitera pengadilan Agaam Kabupaten Nganjuk tanggal 29 April 2015
} 
dilakukan jika ada permohonan, Hakim tidak dapat meletakkan sita tanpa adanya permohonan, yang berhak mengajukan permohonan adalah pihak yang bersengketa itu saja, pihak ke tiga tidak berhak mengajukan permohonan sita. Permohonan sita harus menyebutkan pihak-pihak dalam perkara tersebut, alasan-alasan permohonan sita, barang-barang yang dimohonkan sita dalam petitum sita. ${ }^{57}$

Adapun gugatan perceraian dari seorang suami yang hendak menjatuhkan talak kepada isterinya, harus memenuhi tata cara yang telah ditentukan dalam Pasal 14 sampai dengan Pasal 18 PP No. 9 Tahun 1975 jo. Pasal 66 sampai dengan Pasal 29 Peraturan Menteri Agama No. 3 Tahun 1975 jo. Pasal 66 sampai dengan Pasal 72 UU No. 7 Tahun 1989 tentang Peradilan Agama, yang pada dasarnya sebagai berikut:

1. Suami yang hendak menjatuhkan talak, sebagaimana dimaksud dalam Pasal 38 huruf b. Pasal 39 Undang-Undang Perkawinan jo. Pasal 14 sampai dengan Pasal 18 Peraturan Pemerintah No. 9 Tahun 1975 harus memberitahukan maksudnya dengan surat kepada Pengadilan Agama yang mewilayahi tempat tinggalnya, disertai dengan alasan serta meminta agar diilakukan sidang untuk keperluan itu.

2. Pengadilan Agama mempelajari isi surat pemberitahuan talak dalam waktu selambat-lambatnya 30 (tiga puluh) hari dengan cara memanggil pengirim surat dan juga isterinya untuk meminta penjelasan tentang segala sesuatu yang berhubungan dengan kehendaknya itu.

3. Pengadilan Agama setelah mendapat penjelasan tentang maksud talak itu berusaha mendamaikan kedua belah pihak dan dapat meminta bantuan kepada Badan Penasehat Perkawinan dan Penyelesaian Perceraian (BP4) setempat, agar kepada suami isteri dinasehati untuk hidup rukun lagi dalam rumah tangga.

57 Hasil wawancara dengan Ketua Pengadilan Agama Kabupaten Nganjuk, tanggal 29 April 2015 
4. Pengadilan Agama setelah memperhatikan hasil usaha BP4 bahwa kedua belah pihak tidak mungkin lagi didamaikan dan berpendapat adanya alasan untuk talak maka diadakan sidang untuk menyaksikan talak dimaksud.

5. Suami mengikrarkan talaknya di depan Pengadilan Agama dengan hadirnva isteri atau kuasanya dan menandatangani surat ikrar tersebut.

6. Sesaat setelah dilakukan sidang dan suami mengikrarkan talaknya, Ketua Pengadilan Agama membuat Surat Keterangan tentang terjadinya talak rangkap empat helai pertama beserta ikrar talak dikirimkan kepada Pegawai Pencatat Nikah yang mewilayahi tempat tinggal suami untuk diadakan pencatatan, helai kedua dan ketiga masing-masing diberikan kepada suami dan isteri dan helai keempat disimpan oleh Pengadiian Agama.

7. Suami isteri atau kuasanya dengan membawa surat keterangan tentang terjadinya talak datang ke Pegawai Pencatat Nikah yang mewilayahi tempat tinggal suami untuk mendapatkan Kutipan Buku Pendaftaran Talak.

8. Apabila Pegawai Pencatat Nikah yang mewilayahi tempat tinggal suami berbeda dengan Pegawai Pencatat Nikah tempat pernikahan mereka dilangsungkan, maka satu helai surat keterangan tentang terjadinya talak dikirimkan pula kepada Pegawai Pencatat Nikah tempat pernikahan dilangsungkan.

9. Apabila talak itu terjadi, maka kutipan Akta Nikah masing-masing suami isteri ditahan oleh Pengadilan Agama di tempat talak itu terjadi dan dibuat catatan dalam ruang yang tersedia pada Kutipan Akta Nikah tersebut, bahwa yang bersangkutan telah menjatuhkan/dijatuhi talak.

10. Catatan yang dimaksud nomor 9 di atas berisi tempat terjadinya talak, tanggal talak diikrarkan, nomor dan tanggal Surat Keterangan tentang terjadinya talak dan tanda tangan Panitera. 
11. Perceraian dianggap terjadi beserta akibat-akibatnya terhitung mulai jatuhnya putusan Pengadilan Agama yang telah mempunyai kekuatan hukum yang tetap

Untuk lebih mengetahui proses terjadinya putusan dalam perkara gugatan harta bersama, perlu kiranya dikemukan contoh putusan gugatan harta bersama yang diperoleh dari putusan yang telah mempunyai kekuatan hukum tetap. Putusan yang disampaikan di maksudkan sebagai gambaran secara khusus tentang pembagaian harta bersama, yaitu: Nomor : 338/Pdt.G/2008/PA.NGJ, antara: ABDUSSALAM bin KOHAR dengan melawan NUR HIDAYATI bin ABUBAKAR. Yang dulu merupakan suami istri yang telah menikah pada 9 Nopember 1983 di Kantor Urusan Agama Kecamatan Wonocolo, Kabupaten Surabaya dengan akta nikah nomor 284/05/XI/1983.

Dalam gugatannya (posita) penggugat menyebutkan bahwa selama pernikahan antara mereka tersebut telah memperoleh harta bersama sebagai berikut :

1. 1 (satu) unit mobil merek Toyota Kijang LX 1.8 Warna Silver Metalik B.2303 OT tahun 2003 dibeli tahun 2006 seharga Rp 91.000.000,- (Sembilan puluh satu juta rupiah) sekarang bersama Tergugat;

2. 1 (satu) unit mobil merek DAIHATSU F600 XENIA Warna Coklat Muda Metalik No. Rangka/NIK : MHKFMREEJ4K008240 No. Mesin : DN09242 Nomor plat B 8497 ZM dibeli tahun 2006 seharga Rp 76.000.000,- (Tujuh puluh enam juta rupiah) sekarang bersama Tergugat;

3. 1 (satu) unit mobil SUZUKI ST. 150 Futura Jenis mobil Penumpang dengan Nomor Mesin : G15A 1A-500823 No. Rangka: MHYESL415YJ-500823 Plat No. AG 2660 B warna Abu-abu tahun 2006 dibeli tahun 2006 sekarang bersama Tergugat;-

4. 1 (satu) buah motor merek Honda Supra 125 Tahun 2006 sekarang bersama Tergugat; 
5. 1 (satu) buah televisi merek Sony 29 inc sekarang bersama Tergugat;

6. 1 (satu) buah Televisi merek Sony 20 inc sekarang bersama Tergugat;

7. 1 (satu) buah Televisi merek Panasonic 21 inc sekarang bersama Tergugat;

8. 2 (dua) buah Kulkas merek Denso 1 pintu sekarang bersama Tergugat,

9. 1 (satu) unit kursi jati sekarang bersama Tergugat;

10. 1 (satu) buah lemari jati 2 pintu sekarang bersama Tergugat;

11. 1 (satu) buah lemari bloktik 3 pintu sekarang bersama Tergugat;

12. 1 (satu) buah lemari piring 2 pintu sekarang bersama Tergugat;

13. Seperangkat alat makan sekarang bersama Tergugat;

14. Buku tabungan Haji Bank BRI Cabang Nganjuk atas nama Penggugat sekarang bersama Tergugat;

15. 1 (satu) buah Dipan kayu jati ukuran Nomor dua sekarang bersama Penggugat;

16. 1 (satu) buah Dipan kayu jati ukuran Nomor tiga sekarang bersama Penggugat;

17. 1 (satu) buah Kulkas 1 pintu merek HITACHI sekarang bersama Penggugat;

18. 1 (satu) buah Kipas angin merek Nasional sekarang bersama Penggugat;

19. 1 (satu) buah Mesin Jahit merek Sanghai sekarang bersama Penggugat;

20. 1(satu) buah Radio Compacdisk merek Aiwa sekarang bersama Penggugat;

21.3 (tiga) buah lemari pakaian jati 2 pintu sekarang bersama Penggugat;

22. 1 (satu) buah lemari pakaian gantung bloktik sekarang bersama Penggugat; 
23. 2 (dua) buah meja rias jati sekarang bersama Penggugat;

24. 1 (satu) buah sepeda merek Poligon, sekarang bersama Penggugat;

25. Seperangkat alat makan dan minum berupa piring dan gelas, sekarang bersama Penggugat;

26. 1 (satu) buah Rice cooker merek Cosmos sekarang bersama Penggugat;

27. 1 (satu) unit Sopa sekarang bersama Penggugat

28.1 (satu) Tipe Minicompo merek Politron sekarang bersama Penggugat;

Menurut penggugat harta-harta tersebut di atas adalah harta gono-gini Penggugat dan Tergugat, dan sampai sekarang belum dibagi. Dan untuk menghindarkan dialihtangankannya 3 unit mobil dan 1 buah motor tersebut ke pihak lain secara melawan hukum, maka Penggugat meminta kepada Ketua Pengadilan Agama Kabupaten Nganjuk c/q Majelis Hakim untuk meletakkan sita jaminan sebagaimana tersebut dalam Posita nomor 2 poin 1 s/d poin 4 Penggugat mohon, kepada Ketua Pengadilan Agama Kabupaten Nganjuk c/q Majelis Hakim menerima dan untuk menyidangkan perkara ini, serta memberikan putusan sebagai berikut :

\section{PRIMAIR :}

1. Mengabulkan gugatan Penggugat seluruhnya.

2. Menyatakan sita jaminan sah dan berharga.

a. Menyatakan bahwa harta sebagaimana tersebut dalam Posita angka 2 poin $1 \mathrm{~s} / \mathrm{d}$ poin 28 adalah harta bersama Penggugat dan Tergugat.

b. Menghukum membagi harta bersama tersebut di atas setengah bagian untuk Penggugat dan setengah bagian untuk Tergugat atau apabila tidak dapat dibagi secara natura, harta tersebut dijual melalui Kantor Lelang Negara dan hasilnya dibagi kepada Penggugat dan Tergugat sesuai dengan ketentuan hukum yang berlaku.

c. Menetapkan biaya perkara menurut hokum. 


\section{SUBSIDER:}

Atau menjatuhkan putusan lain yang seadil-adilnya; Menimbang, bahwa hari-hari persidangan yang telah ditetapkan Penggugat dan Tergugat telah hadir sendiri di persidangan; Menimbang, bahwa Majelis Hakim telah berusaha mendamaikan kedua belah pihak baik dalam persidangan maupun di luar persidangan melalui prosedur mediasi dengan Mediator Hakim Pengadilan Agama Kabupaten Nganjuk bernama Masykuri tetapi upaya tersebut tidak berhasil; Penggugat dalam surat gugatannya tertanggal 19 Maret 2008 yang telah ada perubahan permohonan sita jaminan (Conservatoir Beslag) terhadap objek sengketa sebagai berikut :

1. 1 (satu) unit mobil merek DAIHATSU F600 XENIA Warna Coklat Muda Metalik No. Rangka/NIK : MHKFMREEJ4K008240 No. Mesin : DN09242 Nomor plat: AG 8497 ZM dibeli tahun 2006 seharga Rp 76.000.000,- (Tujuh puluh enam juta rupiah) sekarang bersama Tergugat.

2. 1 (satu) unit mobil SUZUKI ST. 150 Futura Jenis mobil Penumpang dengan Nomor Mesin : G15A 1A-500823 No. Rangka: MHYESL415YJ-500823 Plat No. AG 2660 B warna Abu-abu tahun 2000 dibeli tahun 2006 sekarang bersama Tergugat.

3. 1 (satu) buah motor merek Honda Supra 125 Tahun 2006 sekarang bersarna Tergugat.

Bahwa, terhadap permohonan sita jaminan Majelis Hakim telah menjatuhkan Putusan Sela dengan Nomor: 338/Pdt.G/2009/PA.NGJ tanggal 7 Mei 2009 yang amarnya.

Berbunyi sebagai berikut:

1. Menolak permohonan sita jaminan (Conservatoir Beslag) Penggugat terhadap objek sengketa berupa : 
a. 1 (satu) unit mobil merek DAIHATSU F600 XENIA Warna Coklat Muca Metalik No. Rangka/NIK : MHKFMREEJ4K008240 No. Mesin : DN09242 Nomor plat AG 8497 ZM dibeli tahun 2006 seharga Rp 76.000.000,(Tujuh puluh enam juta rupiah) sekarang bersama Tergugat

b. 1 (satu) unit mobil SUZUKI ST.150 Futura Jenis mobil Penumpang dengan Nomor Mesin: G15A 1A-500823 No. Rangka: MHYESL415YJ-500823 Plat No. AG 2660 B warna Abu-abu tahun 2000 dibeli tahun 2006 sekarang bersama Tergugat;

c. 1 (satu) buah motor merek Honda Supra Fit Tahun 2004 sekarang bersarna Tergugat;

2. Menangguhkan biaya perkara ini sampai dengan putusan akhir;

Majelis Hakim dalam perkara ini telah memberikan pertimbangan hukum sebagai berikut :

a. Menimbang, bahwa berdasarkan penjelasan Pasal 49 ayat (2) angka 10 Undang-Undang Nomor 7 tahun 1989 yang telah di rubah dengan Undang-Undang Nomor 3 tahun 2006 tentang Peradilan Agama dan Pasal 88 Kompilasi Hukum Islam perkara ini termasuk wewenang Pengadilan Agama Kabupaten Nganjuk;

b. Menimbang, bahwa yang menjadi pokok alasan Penggugat dalam gugatannya adalah bahwa Penggugat dan Tergugat semula suami isteri, pernah hidup rukun dan damai dan telah dikaruniai 3 (tiga) orang dan selama dalan perkawinan telah terkumpul harta-harta bersama (gono-gini) sebagai mana dalam posita sampai dengan gugatan Penggugat akan tetapi setelah Penggugat dan Tergugat terjadi perceraian dengan putusan Pengadilan Kabupaten Nganjuk

c. Menimbang, bahwa berdasarkan hal di atas maka Penggugat memohon agar harta bersama Penggugat dan Tergugat tersebut 
di atas ditetapkan sebagai harta bersama Penggugat dan Tergugat dan agar harta bersama tersebut dibagi antara Penggugat dan Tergugat;

d. Menimbang, bahwa atas tuntutan Penggugat tentang harta bersama Penggugat dan Tergugat tersebut maka Majelis Hakim akan mempertimbangkan sebagai berikut;

e. Menimbang, bahwa terhadap tuntutan Penggugat pada posita yang berupa sebuah mobil kijang, satu buah mobil Xenia dan satu buah mobil Suzuki Carry yang oleh Penggugat didalilkan sebagai Harta Bersama antana Penggugat dan Tergugat, berdasarkan keterangan Tergugat dalam jawabannya yang didukung oleh dua orang saksi yang bernama Rudi Wahyu Unggul Prastowo dan H Umar dani yang keterangan tersebut tak dibantah oleh Penggugat, bahwa harta bersama tersebut diperoleh dari hasil penjualan rumah Penggugat dan Tergugat di Jakarta dengan nilai jual Rp 410.000.000,-(empat ratus sepuluh juta rupiah) kemudian setelah dikurarg hutang dan pajak uang tersebut sisa Rp 320.000.000,- (tiga ratus dua puluh ju:a rupiah) kemudian uang tersebut sebelum Penggugat dan Tergugat pindah ke Loceret telah dibagi kepada Penggugat dan Tergugat serta anak-anak Penggugat dan Tergugat dengan rincian sebagai berikut:

1) Rp 91.000.000,- (sembilan puluh satu juta rupiah) dibelikan mobil kijarg untuk anak Penggugat dan Tergugat yang pertama ;

2) Rp 50.000.000,- (lima puluh juta rupiah) diberikan kepada anak ke dua;

3) Rp 30.000.000,- (tiga puluh juta rupiah) untuk anak ke 3 yang kemudian setelah sampai di Madiun dibelikan sebuah mobil Suzuki Carry; 
4) Rp 76.000.000,- (tujuh puluh enam juta rupiah) diberikan mobil xenia untuk Tergugat;

5) Rp 40.000.000,- (empat puluh juta rupiah) diberikan kepada Penggugat dan dimasukkan ke bank BCA

6) Sedang sisanya dipakai untuk biaya pindah ( \pm 10 juta), merenovasi rumah orangtua Penggugat (berdasarkan bukti Tg. 9 untuk pembelian material \pm 15.624 .400 ,- di luar biaya tukang) serta biaya makan selama tinggal di Loceret sejak Agustus 2006 sampai dengan 18 April 2007 \pm 8 bulan oleh Penggugat, Tergugat serta 3 orang anak Penggugat dan Tergugat beserta ibu Penggugat dan saudara Penggugat karena gaji Tergugat setelah pensiun hanya Rp 1.300.000,- dan diberikan perhiasan untuk keluarga Tergugat;

f. Menimbang, bahwa ketika pembagian harta-harta tersebut Penggugat dan Tergugat rumah tangganya dalam keadaan rukun, meskipun Penggugat dalam bantahannya terhadap keterangan saksi-saksi Tergugat menyatakan tidak pernah diajak bicara tetapi Tergugat mengakui tentang adanya pembagian tersebut;

g. Menimbang, bahwa berdasarkan pertimbangan-pertimbangan tersebut maka Majelis Hakim bependapat bahwa gugatan Penggugat dalam posita tidak mempunyai alasan oleh karena itu harus ditolak;

h. Menimbang, bahwa mengenai tuntutan Penggugat tentang sepeda motor merek Honda Suprafit nomor polisi AG 6192 BCP yang menurut keterangan Penggugat sebagai harta bersama Penggugat dan Tergugat, ternyata menurut keterangan saksi dipersidangan bahwa sepeda motor merek Honda Supra 125 tersebut adalah kepunyaan anak penggugat dan tergugat dan atas pembelian dia sendiri (Bukti T.8) oleh karena itu 
Majelis Hakim berpendapat tidak terbukti bahwa sepeda motor merek Honda Supra 125 tersebut sebagai harta bersama Penggugat dan Tergugat dengan demikian harus dinyatakan ditolak berdasarkan Pasal 283 R.Bg.

i. Menimbang, bahwa mengenai tuntutan Penggugat tentang buku tabungan haji BRI cabang Nganjuk senilai Rp 1.000.000,- (satu juta rupiali) dan alat-alat rumah tangga baik yang berada pada Penggugat maupun yang berada pada Tergugat sebagairnana dalam posita 2 yang oleh Tergugat dan saksi-saksi Tergugat dipersidangan tidak membantahnya kecuali posita point 8 maka Majelis Hakim menilai bahwa Tergugat telah mengakuinya. Karena itu dengan pengakuan Tergugat tersebut telah terbukti bahwa alat-alat rumah tangga dan buku tabungan tersebut adalah harta bersama Penggugat dan Tergugat yang diperoleh selama dalam perkawinan;

j. Menimbang, bahwa oleh karena harta-harta tersebut di atas telah terbukti sebagai harta bersama Penggugat dan Tergugat selama dalam perkawinan, maka Majelis Hakim perlu menetapkan harta-harta berupa :

1) (satu) buah televisi merek Sony 29 inc;

2) (satu) buah Televisi merek Sony 20 inc;

3) (satu) buah Televisi merek Panasonic 21 inc;

4) (satu) unit kursi jati;

5) (satu) buah lemari jati 2 pintu ;

6) (satu) buah lemari bloktik 3 pintu;

7) (satu) buah lemari piring 2 pintu;

8) Seperangkat alat makan;

9) Buku tabungan Haji Bank BRI Cabang Nganjuk nama Penggugat;

10) 1 (satu) buah Dipan kayu jati ukuran Nomor dua;

11) 1 (satu) buah Dipan kayu jati ukuran Nomor tiga; 1 
12) 1 (satu) buah Kulkas 1 pintu merek HITACHI;

13) 1 (satu) buah Kipas angin merek Nasional;

14) 1 (satu) buah Mesin Jahit merek Sanghai;

15) 1(satu) buah Radio Compacdisk merek Aiwa;

16) 3 (tiga) buah lemari pakaian jati 2 pintu;

17) 1 (satu) buah lemari pakaian gantung bloktik;

18) 2 (dua) buah meja rias jati;

19) 1 (satu) buah sepeda merek Poligon;

20) Seperangkat alat minum berupa piring dan gelas;

21) 1 (satu) buah Rice cooker merek Cosmos;

22) 1 (satu) unit Sopa;

23) 1 (satu) Tipe Minicompo merek Politron.

Adalah harta bersama Penggugat dan Tergugat sesuai Pasal 35 ayat (1) Undang-Undang Nomor 1 Tahun 1974 dan Pasal 1 huruf f Kompilasi Hukum Islam;

a. Menimbang, bahwa sesuai Pasal 97 Kompilasi Hukum Islam, bahwa janda atau duda cerai hidup masing-masing berhak seperdua dari harta bersama, maka Majelis Hakim berpendapat perlu menghukum Penggugat dan Tergugat untuk membagi harta bersama tersebut seperdua untuk Penggugat dan seperdua untuk Tergugat dan apabila harta bersama tersebut tidak dapat dibagi secara natura maka harus dijual dimuka umum melalui Kantor Lelang dan Piutang Negara yang hasil dari penjualan tersebut dibagi dua bagian seperdua untuk Penggugat dan seperdua untuk Tergugat;

b. Menimbang, bahwa hal-hal yang oleh Majelis Hakim tidak dipertimbangkan dalam putusan ini, maka Majelis Hakim berpendapat telah dikesampingkan;

c. Menimbang, bahwa perkara ini termasuk dalam bidang perkawinan, maka sesuai Pasal 89 ayat (1) Undang-Undang Nomor 7 Tahun 1989 yang telah dirubah dan ditambah dengan 
Undang-Undang Nomor 3 Tahun 2006 tentang Peradilan Agama maka biaya yang timbul dalam perkara ini dibebankan kepada Penggugat;

d. Mengingat dan memperhatikan peraturan perundang-undangan yang berlaku dan hukum Islam yang berkaitan dengan perkara ini.

e. Majelis Hakim dalam perkara ini memberikan putusan sebagai berikut:

1) Mengabulkan gugatan Penggugat sebagian;

2) Menetapkan harta-harta berupa:

a) 1 (satu) buah televisi merek Sony 29 inc;

b) 1 (satu) buah Televisi merek Sony 20 inc

c) 1 (satu) buah Televisi merek Panasonic 21 inc;

d) 1 (satu) unit kursi jati;

e) 1 (satu) buah lemari jati 2 pintu ;

f) 1 (satu) buah lemari bloktik 3 pintu;

g) 1 (satu) buah lemari piring 2 pintu;

h) Seperangkat alat makan;

i) Buku tabungan Haji Bank BRI Cabang Nganjuk atas nama Penggugat;

j) 1 (satu) buah Dipan kayu jati ukuran Nomor dua;

k) 1 (satu) buah Dipan kayu jati ukuran Nomor tiga;

1) 1 (satu) buah Kulkas 1 pintu merek HITACHI;

m) 1 (satu) buah Kipas angin merek Nasional;

n) 1 (satu) buah Mesin Jahit merek Sanghai;

o) 1(satu) buah Radio Compacdisk merek Aiwa;

p) 3 (tiga) buah lemari pakaian jati 2 pintu;

q) 1 (satu) buah lemari pakaian gantung bloktik;

r) 2 (dua) buah meja rias jati;

s) 1 (satu) buah sepeda merek Poligon;

t) Seperangkat alat minum berupa piring dan gelas; 
u) 1 (satu) buah Rice cooker merek Cosmos;

v) 1 (satu) unit Sopa;

w) 1 (satu) Tipe Minicompo merek Politron;

Adalah harta bersama Penggugat dan Tergugat;

3) Menghukum Penggugat dan Tergugat untuk membagi harta bersama tersebut seperdua untuk Penggugat dan seperdua untuk Tergugat. Apabila harta bersama tersebut tidak dapat dibagi secara natura harus dijual dimuka umum melalui Kantor Lelang dan Piutang Negara dan hasil dari penjualan terseblit dibagi dua bagian seperdua untuk Penggugat dan seperdua untuk Tergugat.

4) Menolak gugatan Penggugat untuk selebihnya;

5) Menghukum Penggugat mambayar biaya perkara ini sebesar Rp 301.000,- (Tiga ratus satu ribu rupiah).

Perceraian yang terjadi akan berakibat pula terhadap harta bersama yang diperoleh semasa dalam perkawinan, ada juga harta benda yang menjadi hak sepenuhnya masing-masing sebelum terjadi perkawinan ataupun yang diperoleh masing-masing pihak dalam masa perkawinan yang bukan merupakan usaha bersama, misalnya menerima warisan, hibah, hadiah dan lainnya dalam hal yang demikian maka harta tersebut tetap dikuasai masingmasing kecuali ditentukan menjadi harta bersama. Sesuai Pasal 85 Kompilasi Hukum Islam bahwa adanya harta bersama dalam perkawinan itu tidak menutup kemungkinan adanya harta milik masing-masing suami atau isteri. Masalah harta bersama ini baik suami atau isteri dapat mempergunakannya dengan persetujuan salah satu pihak.

Bahkan sepanjang tidak ada perjanjian yang disahkan sebelum perkawinan berlangsung, maka harta benda yang diperoleh selama perkawinan menjadi harta bersama. Tetapi bila saja sebelumnya terdapat suatu perjanjian perkawinan yang dibuat dengan persetujuan kedua belah pihak, maka perjanjian tersebut merupakan perjanjian perkawinan yang sah dan berlaku. Undang-Undang Perkawinan Nomor 1 Tahun 1974 mengenai harta benda 
dalam perkawinan yang terdapat dalam BAB VII Pasal 35, 36 dan 37 sebagai berikut:

\section{Pasal 35}

1. Harta benda yang diperoleh selama perkawinan menjadi harta henda bersama.

2. Harta bawaan dari masing-masing suami dan isteri dari harta benda yang diperoleh masing-masing sebagai hadiah atau warisan adalah di bawah penguasaan masing-masing si penerima para pihak tidak menentukan lain. ${ }^{58}$

\section{Pasal 36}

1. Mengenai harta bersama, suami isteri dapat bertindak atas persetujuan kedua belah pihak.

2. Mengenai harta bawaan masing-masing, suami dan isteri mempunyai hak sepenuhnya untuk melakukan perbuatan hukum mengenai harta bendanya. ${ }^{59}$

\section{Pasal 37}

Bila perkawinan putus karena perceraian, harta bersama diatur menurut hukumnya masing-masing. Sedang dalam Kompilasi Hukum Islam terdapat pada Pasal 1 huruf (f) dan Pasal 85 sebagai berikut : Pasal 1 Huruf (f) menyebutkan : "Harta kekayaan dalam perkawinan atau syirkah adalah harta yang diperoleh baik sendirisendiri atau bersama suami isteri selama dalam ikatan perkawinan berlangsung dan selanjutnya disebut harta bersama, tanpa mempersoalkan terdaftar atas nama siapa pun." 60

Adanya harta bersama dalam perkawinan itu tidak menutup kemungkinan adanya harta milik masing-masing suami atau isteri. Dengan melihat pasal-pasal tersebut di atas, maka dapat ditarik kesimpulan bahwa ketentuan mengenai harta kekayaan yang diatur dalam Undang-Undang Perkawinan dan Kompilasi Hukum Islam dapat dikatakan sudah sejalan dimana harta yang diperoleh selama perkawinan baik karena usaha suami atau isteri bersama-sama otomatis menjadi harta bersama sedangkan harta bawaan tetap dikuasai oleh masing-masing pihak, sekalipun perkawinan telah diputus dan tidak ditentukan dalam perjanjian perkawinan kecuali jika harta bawaan

\footnotetext{
${ }^{58}$ Lihat pasal 35 Undang-undang Perkawinan Nomor 1 Tahun 1974

${ }^{59}$ Ibid., Pasal 36

${ }^{60}$ Ibid., Pasal 37
} 
ditetapkan sebagai harta bersama maka harta bawaan tadi menjadi harta bersama. ${ }^{61}$

Berdasarkan hasil Putusan Pengadilan Agama Kabupaten Nganjuk Nomor : 338/Pdt.G/2008/PA.NGJ terdapat adanya harta bersama mengingat pernikahan antara penggugat dan tergugat tergolong cukup lama. Jadi dalam kasus ini terdapat harta yang merupakan usaha bersama.

Status dari harta bersama tetap sebagai harta bersama milik penggugat dan tergugat tanpa harus memperhatikan atas nama siapa barang-barang tersebut berada Hal ini sesuai dengan Pasal 1 sub f Kompilasi Hukum Islam bahwa harta bersama adalah harta yang diperoleh selama perkawinan berlangsung, baik harta itu terdaftar atas nama suami atau isteri. Serta sesuai Putusan MA tanggal 30 Juli 1974 No. 806 K/Sip/ 1974 mengatakan bahwa masalah atas nama siapa harta terdaftar bukan faktor yang menggugurkan keabsahan suatu harta menjadi obyek harta bersama, asal harta yang bersangkutan dapat dibuktikan diperoleh selama perkawinan serta pembiayaannya berasal dari harta bersama maka harta tersebut termasuk obyek harta bersama. Dalam penjelasan Pasal 35 Undang-Undang Nomor 1 Tahun 1974, dikatakan bahwa apabila perkawinan putus, maka harta bersama tersebut diatur menurut hukumnya masing-masing. Bilamana penjelasan ini dihubungkan dengan Pasal 37 dan penjelasannya, maka dapat disimpulkan bahwa jika perkawinan putus karena perceraian, maka pembagian harta bersama diatur menurut hukumnya masing-masing, yaitu hukum agama, adat dan hukum-hukum lainnya.

Sedangkan harta kekayaan perkawinan dalam Kompilasi Hukum Islam dijelaskan dalam Pasal 86 (2) dan Pasal 87 (1) sebagai berikut :

Pasal 86 (2)

Harta isteri tetap menjadi hak isteri dan dikuasai penuh olehnya, demikian juga harta suami tetap menjadi hak suami dan dikuasai penuh olehnya.

Pasal 87 (1)

Harta bawaan dari masing-masing suami dan isteri dan harta yang diperoleh masing-masing sebagai hadiah atau warisan adalah di bawah 
penguasaan masing-masing, sepanjang para pihak tidak menentukan lain dalam perjanjian perkawinan. Dari uraian di atas, dapat penulis simpulkan bahwa didasarkan Undang-Undang Nomor 1 Tahun 1974 dan Kompilasi Hukum Islam dapat dikatakan sejalan, dengan melihat Pasal di atas dapat disimpulkan bahwa harta yang dipunyai baik harta pribadi maupun harta bawaan tetap dikuasai oleh masing-masing pihak sekalipun perkawinan telah putus kecuali jika ditentukan lain dalam perjanjian perkawinan.

Hasil Putusan Pengadilan Agama Kabupaten Nganjuk Nomor : 338/Pdt.G/2008/PA.NGJ seperti yang telah diuraikan dalam Amar Putusannya terdapatnya harta bersama. Mengenai akibat hukum dari perceraian terhadap harta bersama yaitu bahwa setelah adanya perkawinan maka harta kekayaan yang diperoleh baik dari pihak suami atau isteri menjadi harta bersama sepanjang tidak ditentukan lain dalam perjanjian perkawinan dan jika perkawinan putus, masing-masing berhak 1/2 (seperdua) dari harta tersebut, karena selama perkawinan terdapat adanya harta bersama maka Hakim disini memberikan putusan mengenai besarnya bagian masing-masing. Pengadilan menetapkan pembagian harta bersama tersebut $1 / 2$ (seperdua) bagian untuk penggugat, dan 1/2 (seperdua) bagian untuk tergugat.

Terkait dengan pelaksanaan Eksekusi Pembagian Harta Bersama pada Perkara Nomor Nomor 338/Pdt.G/2008/PA.NGJ. Bahwa sudah menjadi kewajiban bagi seorang suami yang telah ditetapkan Undang-undang Perkawinan dan Kompilasi Hukum Islam yang berkaitan langsung dengan terwujudnya harta bersama adalah kewajiban suami sesuai penghasilannya memberi nafkah, kiswah, biaya-biaya rumah tangga dan tempat kediaman kepada istri. Sebaliknya dengan kewajiban nafkah tersebut, feedback-nya kepada istri adalah kewajiban istri untuk mengelola dan mengatur urusan rumah tangga dengan sebaik-baiknya demikian pula jika istri tidak melaksanakan kewajibannya istri dianggap nusyuz dan akibatnya suami tidak mempunyai kewajiban untuk menafkahi, memberi kiswah, biaya rumah tangga dan tempat kediaman.

Majelis hakim Pengadilan Agama Nganjuk, yang memeriksa dan mengadili perkara nomor 338/Pdt.G/2008/PA.NGJ menyatakan bahwa 
gugatan cerai digabung dengan harta bersama adalah hal yang dibenarkan berdasarkan Pasal 86 ayat (1) Undang-Undang Pengadilan Agama Nomor 7 Tahun 1989 yang berbunyi : Gugatan soal penguasaan anak, nafkah istri dan harta bersama suami istri dapat diajukan bersama-sama dengan gugatan perceraian ataupun sesudah putusan perceraian memperoleh kekuatan tetap.

Berdasarkan prinsip-prinsip hukum harta bersama yang telah ditetapkan oleh Undang-undang Perkawinan dan Kompilasi Hukum Islam maka semua harta benda yang terwujud selama perkawinan menjadi harta bersama. Masalah harta bersama tersebut tidak menjadi persoalan jika memang perkawinan tetap utuh dan baru menimbulkan masalah jika terjadi perceraian.

Apalagi ternyata istri lebih banyak memberikan sumbangsih dalam terbentuknya harta bersama. Maka dalam hal-hal terjadi pergeseran peran sebagaimana yang telah digariskan oleh Undang-undang Perkawinan maupun Kompilasi Hukum Islam maka sangat adil jika dalam hal istri hanya melaksanakan kewajibannya sebagai istri sebagaimana yang telah ditetapkan oleh Undang-undang Perkawinan maupun Kompilasi Hukum Islam, istri tersebut telah mendapatkan setengah maka jika istri tersebut memberikan sumbangsih kepada harta bersama, misal dalam kasus istri juga bekerja maka dalam hal seperti ini akan adil jika pembagian harta bersama dihitung seberapa besar kontribusi istri. Oleh karena itu bisa jadi dalam pembagian harta bersama terjadi pembagian enam banding empat, tiga banding lima dan lain sebagainya. Sebenarnya masih ada upaya-upaya preventif yang diberikan Undang-undang Perkawinan maupun Kompilasi Hukum Islam, untuk menghindari terjadi perselisihan bila di kemudian hari terjadi perceraian khususnya terkait dengan masalah pembagian harta yaitu

Persoalan pelaksanaan putusan (eksekusi) pembagian harta bersama setelah terjadinya pemutusan hubungan perkawinan adalah merupakan masalah yang sangat penting untuk dijamin sebab menyangkut kehidupan khususnya bagi pihak istri setelah berpisah dari suami sebelum ataupun tidak sama sekali istri untuk melakukan perkawinan selanjutnya. Hal ini dapat dilihat dari Yurisprudensi Mahkamah Agung tanggal 9 Oktober 1968 
No.89.K/SIP/1968 yang menyatakan bahwa : selama seorang janda tidak kawin lagi dan selama hidupnya, harta bersama yang dipegang olehnya tidak dapat dibagikan guna menjamin penghidupannya.

Berdasarkan hasil penelitian bahwa bahwa antara suami dan istri keduanya bekerja, dan diantara mereka mempunyai pendapat masing-masing bahwa merekalah yang lebih banyak menghasilkan pendapatan selama perkawinan berlangsung. Untuk itu mereka, walaupun sudah ada putusan Hakim mengenai perceraian, tetapi mereka menentukan lain untuk harta bersama mereka.

Selain itu juga berdasarkan hasil penelitian diketahui bahwa mereka menjalankan putusan Hakim Pengadilan Agama Kabupaten Nganjuk untuk membagi setengah-setengah dari harta bersama mereka. Dari jawaban responden yang dikumpulkan, bahwa mereka tidak begitu mempermasalahkan isi putusan Hakim Pengadilan Agama Nganjuk Nomor 338/Pdt.G/2008/PA.NGJ, hal ini dikarenakan :

1. Hal ini terjadi karena sudah adanya kesadaran yang tinggi mengenai persamaan hak antara pria dan wanita.

2. Mereka ingin selalu menjalani suatu hubungan silaturrahmi yang baik dengan mantannya masing-masing juga keluarganya, tanpa adanya suatu keributan yang terjadi apalagi keributan itu hanya disebabkan suatu persoalan harta.

3. Mengenai keberatan mengenai harta bersama juga tidak dilakukan karena untuk menjaga perasaan anak-anak yang dilahirkan, apalagi yang sudah mengerti tentang kehidupan kedua orang tuanya.

4. Memakan waktu, tenaga dan pikiran bila putusan Pengadilan Agama Nganjuk dilakukan upaya hukum lainnya seperti banding, kasasi dan peninjauan kembali.

5. Dari data di atas, mengenai praktek eksekusi pembagian harta bersama setelah terjadinya perceraian dengan adanya putusan Pengadilan Agama Nganjuk nomor perkara 338/Pdt.G/2008/PA.NGJ, sudah cukup baik. 


\section{PENUTUP}

\section{Kesimpulan}

Berdasarkan data yang penulis dapatkan di Pengadilan Agama Kabupaten Nganjuk nomor 338/Pdt.G/2008/PA.NGJ, maka peneliti dapat mengambil kesimpulan sebagai berikut :

a. Pembagian harta bersama di Pengadilan Agama Nganjuk pada perkara nomor Nomor 338/Pdt.G/2008/PA.NGJ, dilakukan atas dasar Undang-Undang Nomor 1 Tahun 1974 tentang Perkawinan dan Kompilasi Hukum Islam, maka harta kekayaan yang diperoleh baik dari pihak suami atau isteri menjadi hak bersama sepanjang tidak ditentukan lain dalam perjanjian perkawinan dan jika perkawinan putus, masing-masing berhak $1 / 2$ (seperdua) dari harta tersebut, karena selama perkawinan terdapat adanya harta bersama, maka Hakim memberikan putusan mengenai besarnya bagian masingmasing. Pengadilan menetapkan pembagian harta bersama tersebut $1 / 2$ (seperdua) bagian untuk penggugat dan 1/2 (seperdua) bagian untuk tergugat.

b. Pelaksanaan eksekusi pembagian harta bersama pada perkara Nomor 338/Pdt.G/2008/PA.NGJ adalah dilakukan dengan sukarela oleh para pihak karena mereka tidak begitu mempermasalahkan putusan pengadilan Agama Nganjuk, karena tujuan utama mereka (penggugat dan tergugat) adalah bercerai. 


\section{DAFTAR PUSTAKA}

Abdul Kholiq, Hukum Pidana (Buku Panduan Kuliah), Fakultas Hukum Universitas Islam Indonesia, Yogyakarta, 2002

Adami Chazawi, Pelajaran Hukum Pidana, PT Raja Grafindo Persada, Jakarta, 2001

Andi Hamzah, Penghantar Hukum Acara Pidana, Ghalia Indonesia, Jakarta, 2002 Aruan Sakijdjo dan Bambang Poernomo, Hukum Pidana,Dasar Aturan Hukum Pidana Kodifikasi, Ctk. Pertama, Ghalia Indonesia, Jakarta, 1990

Bambang Poernomo, Pokok-pokok Tata Acara Peradilan Pidana dilndonesia dalam Undang-Undang R.No. 8 Tahun 1981,Ctk. Pertama, Liberty, Yogyakarta, 1993

Barda Nawawi Arief, Teori-teori\&Kebijakan Pidana , Edisi Revisi, Alumni, Bandung, 1998

, Bunga Rampai Kebijakan Hukum Pidana, Edisi Revisi, Citra Aditya Bakti, Bandung, 2002

----------, Beberapa Aspek Kebijakkan Penegakkan \& Pengembangan Hukum Pidana, Edisi Revisi, Citra Aditya Bakti, Bandung, 2005

-, Asas-asas Hukum Pidana, Ctk. kelima, Ghalia Indonesia, Jakarta, 1985

C.S.T. Kansil, Hukum Tata Negara Indonesia, PT. Rineka Cipta, Jakarta, 2002

Djoko Prakoso, Masalah Pemberian Pidana dalam Teori dan Praktetk

Pengadilan, Jakarta Timur, Ghalia Indonesia. 1984

D. Schaffmeister, N. Keijzer dan PH. Sutorius, Hukum pidana, Ctk. Pertama, Liberty, Yogyakarta, 1995

Moeljatno, Asas-asas Hukum Pidana, Jakarta, Rineka Cipta, 1993

Muladi dan Dwidja Priyatno, Pertanggungjawaban Korporasi dalam Hukum Pidana, Ctk. Pertama, Sekolah Tinggi Hukum Bandung, Bandung, 1991

Mulyana W Kusumah, Analisa Kriminologi Tentang Kejahatan-kejahatan Kekerasan, Jakarta, Ghalia Indonesia, 1980 
M. Yahya Harahap, Pembahasan Permasalahan dan Penerapan KUHAP (penyidikan dan penuntutan ), Sinar Grafika, Jakarta, 2007

Nanda Agung Dewantara, 1988, Kemampuan Hukum Pidana dalam Menanggulangi Kejahatan-kejahatan Baru yang Berkembang dalam Mayarakat, Yogyakarta, Liberty.

Roeslan Saleh, Sifat Melawan Hukum dari Perbuatan Pidana, Ctk. Keempat, Aksara Baru, Jakarta, 1983

R. Wirjono Prodjodikoro, Perbuatan Melawan Hukum, Mandar Maju, Bandung, 2000.

----------, Tindak-tindak Tertentu di Indonesia, Bandung Eresco, 1986

R.Soesilo, Kitab Undang-undang Hukum Pidana, ctk. Ulang, Politea, Bogor, 1996.

Samidjo, Hukum Pidana (Ringkasan \& Tanya Jawab), Armico, Bandung, 1985.

Setiyono, Kejahatan Korporasi, Ctk. Pertama, Averros Press\&Fakultas Hukum Unversitas Medeka Malang\&Pustaka Pelajar, Malang \& Yogyakarta, 2002.

Soerjono Soekanto, Etial Kriminologi Suatu Pengantar, Jakarta Timur, Ghalia Indonesia, 1981

Sudikno Mertokusumo, Mengenal Hukum, Yogyakarta, Liberty, 1985

Topo Santoso Dan Eva Achjani Zulfa, Kriminologi, Raja Graffindo Persada, Jakarta, 2001

Utrecht, Hukum Pidana II, Ctk. Ketiga, Bulan Bintang, Jakarta, 1976

------------, Hukum Pidana I, Universitas Jakarta, Jakarta, 1958

Van Apeldoorn, Pengantar Ilmu Hukum, Pradnya Paramita, Jakarta 1954 